\title{
Causes and Effects of Cost Overruns in Public Building Construction Projects Delivery, In Imo State, Nigeria.
}

\author{
Anyanwu Columbus Ikechukwu ${ }^{1}$, Fidelis, I. Emoh ${ }^{2}$, Okorocha A. Kelvin ${ }^{3}$ \\ ${ }^{1}$ Associate Professor, School of Management Technology Department of Project Management Technology \\ Federal University of Technology, Owerri, Imo State, Nigeria. \\ ${ }^{2}$ Ph.D, Department of Estate Management Nnamdi Azikiwe University, Awka, Anambra State, Nigeria. \\ ${ }^{3}$ Ph.D., School of Management Technology Department of Project Management Technology Federal University \\ of Technology, Owerri, Imo State, Nigeria.
}

\begin{abstract}
This study examined the causes and effects of cost overruns in public building construction project delivery in Imo State, Nigeria. Specifically, the study examined the profile characteristics of the building construction project workers, examined also the nature of cost overruns in building projects execution in Nigeria, identified the main causes of cost overruns on building construction projects in Nigeria, ascertained the effects of cost overruns on building construction industry and on the economy of Nigeria, in general and determined the factors that can prevent cost overruns in public building construction projects in Nigeria. Multistage sampling technique was used to select a sample of 100 building construction project workers. Data were collected using structured questionnaire and were analysed using mean, frequency counts and percentages. Results showed that $80 \%$ of the workers were males, $54 \%$ were between the ages of $26-35$, and $80 \%$ were married, $85 \%$ had secondary and tertiary education. The result also showed that cost overruns occur when there is an underestimation of actual cost during the budgeting of the building construction project $\bar{X}=2.19)$, when cost escalation occurs due to factors such as inflation $(\bar{X}=2.28)$, when construction projects are not completed on time, within budget and with the appropriate technical or quality performance $(\bar{X}=2.46)$, and when there is an extra cost incurred beyond the contractual cost agreed during the tender stage of the project $(\bar{X}=2.23)$. Further, the results showed that the main causes of cost overruns in building construction projects in Nigeria include difficulty in obtaining construction materials $(\bar{X}=2.19)$, deficiencies in prepared cost estimates $\bar{X}=2.11)$, unexpected subsoil conditions $(\bar{X}=2.08)$, problems in finance and payment arrangements $(\bar{X}=2.09)$, design changes $(\bar{X}=2.72)$ and availability of skilled labour $(\bar{X}=2.24)$. The results also showed that the effects of cost overruns on the building construction and on the Nigerian economy in general include added cost over and above those initialy agreed upon by the client $(\bar{X}=2.40)$, less returns on investment on the part of the contractor $(\bar{X}=2.39)$, higher prices to the end user $(\bar{X}=2.38)$, tarnishing of the reputations of the professionals $(\bar{X}$ $=2.15)$, and loss of profits for the contractor $(\bar{X}=2.40)$. The effects on the construction industry is project abandonment and drop in building activities $(\bar{X}=2.48)$, and also decrease in property and service production for the nation $(\bar{X}=2.45)$; also decrease in the rate of national growth $(\bar{X}=2.10)$. The results also showed that the factors that can help reduced or prevent cost overruns in public building construction projects in Nigeria include the application of project management scheduling tools $(\bar{X}=2.68)$,working strictly within the scope originally planned for a project $(\bar{X}=$ $2.60)$, planning projects properly before the commencement of project execution $(\bar{X}=2.58)$, selection of contractors with adequate experiencel the financial ability to handle building construction projects contract $(\bar{X}=2.33)$ and ensuring that communication gaps do not exist between the stakeholders of the building construction projects $(X=$ 2.35). The study therefore, recommends that building construction projects delivery decision makers should endeavour to implement the findings of research in order to encourage project execution success.
\end{abstract}

Keywords: Cost overrun, public building, construction project, effect of, cost overrun, project management.

\section{Introduction}

In today's construction industry, cost overrun is a very common phenomenon worldwide. The problem of cost overrun is critical and needs to be studied more to alleviate the issue (Angelo and Reina, 2002). In a study conducted by Omoregie and Radford (2006), it was reported that a minimum average of cost escalation in construction projects in Nigeria is $14 \%$ every year. Cost overruns in building construction projects can occur due to various causes, and a number of researchers have investigated the various causes of cost overruns. For instance, Ameh et al., (2010) in his study investigating 42 cost overrun cases, found that lack of experience of contractors, cost of material, fluctuation in the prices of material, frequent design changes, economic stability, high interest rates charged by banks on loans and mode of financing, bonds and payments as well as fraudulent practices and kickbacks were dominant factors causing cost overruns in Nigeria. Doloi (2011) found out in his work that factors causing cost overruns in construction projects in Nigeria were increment of materials prices, delay in supply of raw materials and equipment by contractors, fluctuations in the cost of building materials, unsettlement of the local currency in relation to dollar value, project materials monopoly by some suppliers, resources constraint of funds and 
associated auxiliaries, not being ready, lack of cost planning/monitoring during pre-and post-contract stages, improvements to standard drawings during construction stage, design changes and inaccurate quantity take-off. The problem of cost overruns is not only a Nigerian thing. It is a problem worldwide for example, Le-Hoai et al. (2008) found out that poor site management and supervision, poor project management assistance, financial difficulties of owner, financial difficulties of contractor, design changes were most severe and common causes of cost overrun in Vietnamese construction industry. Also, Memon et al. (2010) investigated large projects in Malaysia and found out that cash flow and financial difficulties faced by contractors, contractor's poor site management and supervision, inadequate contractor experience, shortage of site workers, incorrect planning and scheduling by contractors were most severe factors that cause cost overruns, while changes in scope of project and frequent design changes were least affecting factors on construction cost. Koushki et al. (2005) studied private residential projects in Kuwait and concluded that contractor related issues, material related problems and financial constraints were major reasons of cost overruns.

Cost is one of the primary measures of a project's success. This is true, especially for public projects in developing countries like Nigeria, because public construction projects in these countries are executed with scarce financial resources. Most literature review on construction projects suggested that the common criteria for project success are generally considered to be cost, time and quality Frimpong et al, (2003). A project is deemed successful if it was completed on budget, on schedule, conformed to user expectations, met specifications, attained quality of workmanship and minimized construction aggravation Olawale et al., (2010). Generally, a project is considered successful in Nigeria if the project is completed within a stated cost or budget, getting the project into use by a target date, meets the technical specification, and if there is a high level of satisfaction concerning the project outcome among the project participants.

In Nigeria, the present state of the construction industry falls short of meeting domestic and international quality standards and the performance demand expected from the sector. Construction projects especially building projects, have problems with construction techniques and management as well as limitations of funds and time. The critical problems are inability to complete the projects on schedule, low quality work and cost overruns.. In general, most (if not all), construction projects experience time overrun and cost overruns during their execution phase. An examination of the records of more than four thousand construction projects by Morris et al, (1990), showed that projects were rarely finished on time or within their allocated budgets in Nigeria.

This study therefore would add to knowledge by carrying out this research on the building sub-sector of the Nigerian construction project delivery. The study therefore seeks to:

i. examine the profile characteristics of the building construction project workers,

ii. examine the nature of cost overruns in building projects execution in Nigeria,

iii. identify the main causes of cost overruns on the building construction projects in Nigeria,

iv. ascertain the effects of cost overruns on the building construction industry and on the economy of Nigeria, in general,

v. determine the factors that can help prevent cost overruns in public building construction projects in Nigeria.

\section{Literature Review}

\section{A. THE NIGERIAN BUILDING CONSTRUCTION INDUSTRY}

The building construction industry is an important industry that plays a vital role in the socio-economic growth of Nigeria. Economically, it contributes in significant improvement in the overall GDP of the country. It also improves the quality of life by providing the necessary infrastructure such as roads, hospitals, schools and other basic and enhanced facilities. Hence, it is fundamentally crucial to make construction projects completed successfully within time, budget and expected quality. However, being a complex, fragmented and schedule driven industry it always faces chronic problems such as low quality of productivity, cost overruns, time overruns, construction waste management and others. Of these, cost overruns is a severe problem Olawale et al, 2010) because it affects the overall development of the country.

Cost overruns is a global phenomenon in the construction industry where, very rarely, projects are finished within the budgeted cost. In a global study (Flyvbjerg et al., 2003) on construction project performance, cost overrun was identified as the major problem where 9 out of 10 projects faced the overrun in the range of 50 to $100 \%$ and these overruns produce immediate effects on construction stakeholders and on the country's economy (Azhar et al., 2010). This is because the construction industry plays a vital role in economic and social growth of any country. To prevent poor cost performance, it is often required to evaluate a project's vulnerability of cost overruns before it is too late (Cha and Shin, 2011). According to Ibrahim et al. (2010), in Nigeria very little research has been carried out by academic and practitioners on problems faced by the construction industry; more specifically there is lack of investigation on construction cost factors. 


\section{B. NATURE OF COST OVERRUNS IN THE NIGERIAN BUILDING CONSTRUCTION INDUSTRY}

The sad truth about construction cost overrun is that it has been a fact of life since Biblical times "For which of you, intending to build a tower, sitteth not down first, and counteth the cost, whether he have sufficient to finish it?" Luke, 14:28; quoted by Arditi et al, (2011). The problem of cost overrun, especially in the construction industry is a worldwide phenomenon and its ripples are normally a source of friction among clients, consultants and contractors on the issue of project cost variation. Project cost overruns create a significant financial risk to clients. However, in spite of the risks involved, the history of the construction industry is full of projects that were completed with significant cost overruns (Greedy, 2005). Cost overruns has been defined differently by different authors. Some of these include:

a) Costs overrun is an instance in which the provision of contracted goods or services are claimed to require more financial resources than was originally agreed between a project sponsor and a contractor [Ahuja et al., (2009).

b) Cost overrun is the amount by which actual costs exceed the baseline or approved costs (Wideman, 2006).

c) Cost overrun is the difference between the original cost and the actual cost when the project is completed (Avots, 1983). Actually, Avots, (1983) used the word cost growth instead of cost overrun.

For the purpose of this research cost overrun is defined as the difference between the final actual cost of a construction project at completion and the contract amount, agreed by and between the client (the project owner) and the contractor during signing of the contract.

\section{CAUSES OF COST OVERRUNS IN PUBLIC BUILDING PROJECTS}

Angelo and Reina, (2002), stated that cost overrun is a major problem in both developed and developing countries. Several studies of major projects show that cost overruns are common. The causes of cost overrun in construction projects are varied, some are not only hard to predict but also difficult to manage (Morris, 1991). According to a study made in Turkey by Arditi, et al, (2011), the important sources for cost overruns were found to be inflationary pressures, increases in material prices and workmen's wages, difficulties in obtaining construction materials, construction delays, deficiencies in cost estimates prepared by public agencies and unexpected sub soil conditions were the most important sources for cost overruns. Kaming, et al, (1997), studied the factors influencing construction time and cost overruns for high-rise projects in Indonesia, and pointed out that the major factors influencing cost overrun were material cost increase due to inflation, inaccurate material estimating and the degree of project complexity. Mansfield, Ugwu, and Doran, (1994), found that cost overrun is attributed to problems in finance and payment arrangements, poor contract management, material shortages, changes in site conditions, design changes, mistakes and discrepancies in contract documents, mistakes during constructions, price fluctuations, inaccurate estimating, delays, additional work, shortening of contract periods, and fraudulent practices and kickbacks. Ibbs, (1928), attributes cost overruns to several factors that are either not controllable or that to a varying degree are unmanageable. They include the accuracy of original cost estimate, degree of government regulation and control, construction completion delays, number of design changes, and labor related matters such as their availability, skills, and increases in fringe benefits. According to Robert, (2007), project owners identified five reasons for project cost overruns and these reasons were: incomplete drawings, poor pre-planning process, escalating cost of materials, lack of timely decisions and excessive change orders.

According to Cantrelli, (2007), the following are the factors that change the cost of the construction projects through time: poor project management, design changes, unexpected ground conditions, inflation,, shortages of materials, change in exchange rates, inappropriate contractors, funding problems, etc.

In developing countries, the lack of proper phasing of construction projects can contribute to the economy to become 'overheated'. This leads to shortage of construction materials as the demand will exceed the supply; this in turn leads to a climb in the cost of construction materials, and this inevitably gives rise to project cost overruns, with consequential effects on inflation and a decline on efficient activity in the construction industry (Ugwu, 1994).

\section{EFFECTS OF COST OVERRUNS}

Cost overruns have obvious effects for the key stakeholders in particular, and on the construction industry in general. To the client, cost overruns implies added costs over and above those initially agreed upon at the onset, resulting in less returns on investment. To the end user, the added costs are passed on as higher rental/lease costs or prices.

To the professionals, cost overrun implies inability to deliver value for money and could well tarnish their reputations and result in loss of confidence reposed in them by clients.

To the contractor, it implies loss of profit for non-completion, and defamation that could jeopardize his/her chances of winning further jobs, if at fault. To the industry as a whole, cost overruns could bring about project abandonment and a drop in building activities, bad reputation,, and inability to secure project finance or 
securing it at higher costs due to added risks (Mbachu,et al 2004). All these consequences undermine the viability and sustainability of the construction industry.

According to Arditi, et al, (2011), the effects of cost overrun are not confined to the construction industry but are reflected in the state of the overall economy of a country. They state that delays and cost overruns in construction projects prevent the planned increase in property and service production from taking place, and this phenomenon in turn affects, in a negative way, the rate of national growth.

Angelo and Reina, (2002), state that the problem of cost overrun is critical and needs to be studied further to alleviate the problem in the future. Project cost overruns can cause a slower payout and reduce an early return on the client's or project owner's investment.

\section{E. FACTORS THAT CAN PREVENT/REDUCE COST OVERRUNS}

According to experts, cost overruns can be remedied or prevented from occurring through a conscious estimating that will make the estimator to double check the estimate and include supplier's and some contractor's pricing. A triple check by a competent, preferably a project manager, is necessary to prevent avoidable errors and to review estimates. Comparing cost by whatever unit measure is an appropriate practice.

Another way to prevent cost overrun is by use of change order. A change order request can be difficult when conditions unaware to the contractor are lacking proper documentation. A client's practicality can help determine whether to grant a change order or not. Another way to prevent cost overruns is to schedule rental equipment in an efficient manner in other to prevent squandering cost. Doloi, A. (2011), Rental tools and equipment should not be allowed to stay on a project if they are not being used. Proper checking of invoices is another way of prevent cost overruns from occurring. Invoices require being checked against the purchase order and delivery and pick-up receipts.

Experts believe that appropriate use of proper project management tools and techniques can also prevent cost overruns from occurring. Also, the importance of efficient communication among the stakeholders cannot be underestimated. Communication gaps should not exist between the client, the professionals, the contractor and the rest of the project team members during project delivery.

\section{Methodology}

The study was conducted in Owerri Imo State Nigeria. A total of ten Local Government Areas (L.G.As) in Owerri Imo State were randomly chosen. The L.G.As are Aboh Mbaise, Ahiazu Mbaise, Ezinihite Mbaise, Ikeduru, Mbaitoli, Ngor Okpala, Ohaji/Egbema, Owerri Municipal, Owerri North and Owerri West. Multistage sampling technique was used to select the sample. The first stage involved the selection of the ten L.G.As in the state. The second stage involved the selection of two communities from each of the selected L.G.As to give a total of 20 communities, using simple random sampling technique. The third stage comprised the selection of five construction project stakeholders that include the professionals (civil Engineer, Architect, quantity surveyor, project managers etc), the contractor, the client, the technicians (Masons, Carpenters, etc) and materials suppliers to give a total of one hundred (100) building construction projects workers, using simple random sapling technique. The researchers went to each of the ten L.G.As and obtained the list of the respondents.

Data for the research was obtained from both primary and secondary sources. A set of structured questionnaire was used to elicit data from the respondents. The data were analyzed using frequency counts, percentages and mean represented in tabular form. This was used for objective (i). But the likert measurement scale was used for objectives (ii), (iii), (iv) and (v). The Likert measurement scale formula used is as follows:

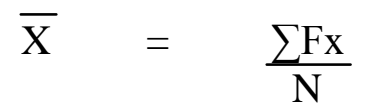

where,

$\begin{array}{lll}\overline{\mathrm{X}} & = & \text { The mean score } \\ \sum & = & \text { Summation sign } \\ \mathrm{Fx} & = & \text { Frequency } \\ \mathrm{N} & = & \text { No of respondents }\end{array}$

The scaling statements used were: "strongly agree", "agree" and "not agree", for objectives (ii), (iii), (iv) and (v). The mean of the measurement scale was calculated as follows:

$$
\frac{3+2+1}{3}=\frac{6}{3}=2
$$


The decision rule is therefore based on this mean value of 2 . Any mean value greater or equal to 2 is therefore acceptable. Mean values less than 2 are not acceptable.

\section{Results And Discussion}

\section{A. PROFILE CHARACTERISTICS OF THE BUILDING CONSTRUCTION PROJECT WORKERS}

Table 1 shows that majority of the building construction workers $(80 \%)$ were males; a greater proportion are within the age range of 26-35 years (54\%), majority (80\%) were married. The table also showed that majority of them were secondary school leavers. (45\%), while also a good number $(40 \%)$ had tertiary diploma/degree levels of education. This shows that the respondents are knowledgeable and therefore would understand and interpret research questions. This is in line with Baridan, (2005) who pointed out that research respondents should be informed and knowledgeable about the subjects which they are given questionnaire to respond.

Table 1: Profile characteristics of the building construction project workers

\begin{tabular}{|l|c|c|}
\hline Profile Characteristics & Frequency & Percentage \\
\hline Sex & 80 & \\
Male & 20 & 80.00 \\
Female & & 20.00 \\
\hline Age (in years) & 6 & \\
Below 25 & 54 & 6.00 \\
$26-35$ & 30 & 54.00 \\
$36-45$ & 10 & 30.00 \\
Above 46 & & 10.00 \\
\hline Marital status & 20 & 20.00 \\
Single & 80 & 80.00 \\
Married & 15 & \\
\hline Level of Education & 45 & 15.00 \\
Primary & 15 & 45.00 \\
Secondary (O' Level) & 25 & 15.00 \\
Diploma Holder & & 25.00 \\
Degree Holder & 5 & 5.00 \\
\hline Work Experience (in years) & 18 & 18.00 \\
$1-5$ & 31 & 31.00 \\
$6-10$ & 30 & 30.00 \\
$11-15$ & 16 & 16.00 \\
$16-20$ & & \\
$21-$ above & & \\
\hline
\end{tabular}

Source: Field Survey, 2017

\section{B. NATURE OF COST OVERRUNS IN BUILDING CONSTRUCTION PROJECTS.}

The results in table 2 show the perceived nature of cost overruns in building construction projects in Nigeria. The respondents agreed that cost overruns occurs when there is an underestimation of actual cost during the budgeting of the building construction project $(\overline{\mathrm{X}}=2.19)$; when cost escalation occurs due to factors such as inflation $(\overline{\mathrm{X}}=2.28)$; when construction projects are not completed on time, within budget and with the appropriate technical or quality performance $(\bar{X}=2.46)$; when there is an extra cost incurred beyond the contractual cost agreed during the tender stage of the project $(\overline{\mathrm{X}}=2.23)$. This agrees with Ahuja et al., (2009)who agrees that cost overruns is the difference between the final actual cost of a building construction project at completion and the contract amount, agreed by and between the client (the project owner) and the contractor during signing of the contract.

Table 2: Respondents information on the nature of cost overruns in Building Construction Projects.

\begin{tabular}{|l|c|c|c|c|c|}
\hline \multicolumn{1}{|c|}{ Nature of Cost Overruns } & $\begin{array}{c}\text { Strongly } \\
\text { Agree (3) }\end{array}$ & $\begin{array}{c}\text { Agree } \\
(\mathbf{2})\end{array}$ & $\begin{array}{c}\text { Disagree } \\
(\mathbf{1})\end{array}$ & $\begin{array}{c}\text { Mean } \\
\mathbf{X}\end{array}$ & Remarks \\
\hline $\begin{array}{l}\text { Occurs when there is underestimation of actual } \\
\text { cost during budgeting }\end{array}$ & $32(96)$ & $55(110)$ & $13(13)$ & 2.19 & Agree \\
\hline Cost escalation due to factors such as inflation & $34(102)$ & $60(120)$ & $6(6)$ & 2.28 & Agree \\
\hline $\begin{array}{l}\text { When construction projects are not completed } \\
\text { on time, within budget and with appropriate } \\
\text { quality performance }\end{array}$ & $56(168)$ & $34(68)$ & $10(10)$ & 2.46 & Agree \\
\hline $\begin{array}{l}\text { When there is extra cost beyond the contractual } \\
\text { cost agreed during the tender stage }\end{array}$ & $35(105)$ & $53(106)$ & $12(12)$ & 2.23 & Agree \\
\hline
\end{tabular}

Source: Field Survey, 2017 


\section{MAIN CAUSES OF COST OVERRUNS ON PUBLIC BUILDING CONSTRUCTION PROJECTS IN NIGERIA}

Table 3 shows the main causes of cost overruns in building construction projects in Nigeria. These include difficulty in obtaining construction materials which had a mean of 2.19, deficiencies in prepared cost estimates with a mean of 2.11, unexpected sub-soil conditions with a mean score of 2.08, problems in finance and payment arrangements with $\bar{X}=2.09$, design changes, with a mean of 2.72 , which the respondents agreed is the major cause of cost overruns in building construction projects, and availability of skilled labour with the mean of 2.24. This is in agreement with the findings of Robert (2007). However, the respondents disagreed that poor contract management $(\bar{X}=1.92)$ was a major cause of cost overruns, since according to them, that could mainly result to poor quality work. The respondents also disagreed that fraudulent practices and Kickbacks (with $\overline{\mathrm{X}}=1.81$ ) was a main cause of cost overruns in building construction projects in Nigeria.

Table 3: Distribution of respondents according to their opinions about the main causes of cost overruns in Building construction projects in Nigeria.

\begin{tabular}{|c|c|c|c|c|c|}
\hline Main Causes of Cost Overruns & $\begin{array}{l}\text { Strongly } \\
\text { Agree (3) }\end{array}$ & $\begin{array}{l}\text { Agree } \\
(2)\end{array}$ & $\begin{array}{l}\text { Disagree } \\
(1)\end{array}$ & $\frac{\text { Mean }}{\mathrm{X}}$ & Remarks \\
\hline Difficulty in obtaining construction materials & $34(104)$ & $51(102)$ & $15(15)$ & 2.19 & Agree \\
\hline Deficiencies in prepared cost estimates & $29(87)$ & $55(110)$ & $14(14)$ & 2.11 & Agree \\
\hline Unexpected subsoil conditions & $26(78)$ & $56(112)$ & $18(18)$ & 2.08 & Agree \\
\hline Problems in finance and payment arrangements & $26(78)$ & $57(112)$ & $17(17)$ & 2.09 & Agree \\
\hline Poor contract management & $28(84)$ & $54(108)$ & $16(16)$ & 1.92 & Disagree \\
\hline Design changes & $76(228)$ & $20(40)$ & $4(4)$ & 2.72 & Agree \\
\hline Additional work & $21(63)$ & $39(78)$ & $40(40)$ & 1.81 & Disagree \\
\hline Fraudulent practices and kickbacks & $42(126)$ & $40(40)$ & $18(18)$ & 2.24 & Agree \\
\hline Availability of skilled labour & $41(123)$ & $33(66)$ & $26(26)$ & 2.15 & Agree \\
\hline
\end{tabular}

Source: Field Survey, 2017

\section{EFFECTS OF COST OVERRUNS ON BUILDING CONSTRUCTION INDUSTRY AND ON THE ECONOMY OF NIGERIA IN GENERAL}

Table 4 shows the respondents mean scores on the effects of cost overruns on the building construction industry and on the Nigerian economy in general/ respondents agreed with most of the variables considered. They include added cost over and above those initially agreed upon by the client $(\bar{X}=2.40)$, less returns on investment on the part of the contractor $(\bar{X}=2.39)$, higher prices or rent to the end user $(\bar{X}=2.38)$, tarnishing of reputations of the professionals $(\bar{X}=2.15)$, loss of profits for the contractor $(\bar{X}=2.40)$. Project abandonment and drop in building activities for the construction industry $(\bar{X}=2.48)$, decrease in property and service production for the nation $(\overline{\mathrm{X}}=2.45)$, and for the nation also, rate of national growth is affect $(\overline{\mathrm{X}}=2.10)$. These results agree with the information revealed in the literature review (Mbachu, et al, 2004), on the effects of cost overruns on the stakeholders of the construction industry, the industry itself and the Nigerian economy in general.

Table 4: Distribution of Respondents according to their opinions about effects of cost overruns on the building construction industry on the economy of Nigeria in general

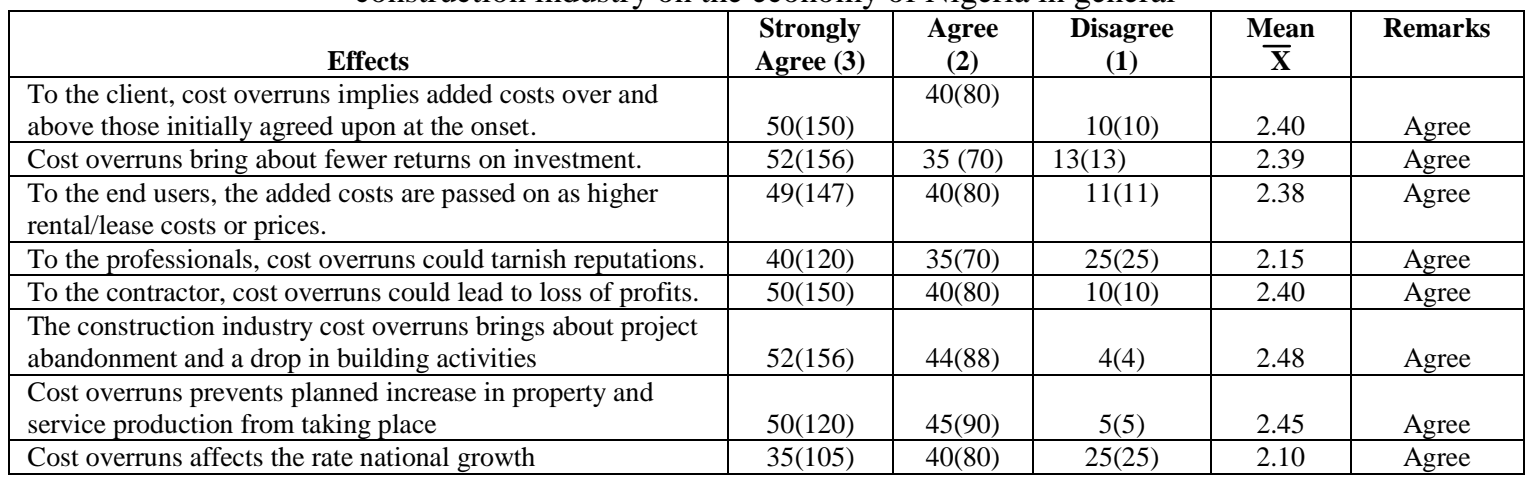

Source: Field Survey, 2017

Project abandonment and drop in building activities for the construction industry $(\overline{\mathrm{X}}=2.48)$, decrease in property and service production for the nation $(\bar{X}=2.45)$, and for the nation also, rate of national growth is affect $(\bar{X}=2.10)$. these results agree on the information revealed in the literature review Mbachu, et al (2004), on the effects of cost overruns on the stakeholders of the construction industry, the industry itself and the Nigerian economy in general. 


\section{E. FACTORS THAT CAN HELP REDUCE/PREVENT COST OVERRUNS IN PUBLIC BUILDING CONSTRUCTION PROJECTS IN NIGERIA.}

Date in table 5 shows the factors that can help reduce or prevent cost overruns in public building construction projects in Nigeria, in the opinion of the respondents, and their mean scores. The respondents agreed with most of the factors that can help remedy cost overruns in building construction projects. These factors include application of project management scheduling tools $(X=2.68)$, working strictly within the scope originally planned for a project $(\bar{X}=2.60)$, planning projects properly before the commencement of project execution $(\overline{\mathrm{X}}=2.58)$, selection of contractors with adequate experience and the financial ability to handle building construction projects contracts $(\bar{X}=2.33)$ and ensuring that communication gaps do not exist between the stakeholders of building construction projects $(\bar{X}=2.35)$. The respondents disagree that adequate money has to be available before project implementation is commenced. All these findings agree with the information revealed in the literature review.

Table 5: Distribution of Respondents according to the factors they consider as the remedy to cost overruns in building construction projects delivery in Nigeria.

\begin{tabular}{|c|c|c|c|c|c|}
\hline Remedy of Cost Overruns & $\begin{array}{l}\text { Strongly } \\
\text { Agree (3) }\end{array}$ & $\begin{array}{l}\text { Agree } \\
(2)\end{array}$ & $\begin{array}{l}\text { Disagree } \\
\text { (1) }\end{array}$ & $\frac{\text { Mean }}{\mathrm{X}}$ & Remarks \\
\hline Use of good project management scheduling tool & $70(210)$ & $28(56)$ & $2(2)$ & 2.68 & Agree \\
\hline $\begin{array}{l}\text { Staying within the scope originally planned for the } \\
\text { project }\end{array}$ & $65(195)$ & $30(60)$ & $5(5)$ & 2.60 & Agree \\
\hline $\begin{array}{l}\text { Proper planning of project activities before } \\
\text { commencing project execution }\end{array}$ & $62(186)$ & $34(68)$ & $4(4)$ & 2.58 & Agree \\
\hline $\begin{array}{l}\text { Ensuring that adequate funds are available before } \\
\text { projects are started }\end{array}$ & $22(66)$ & $23(46)$ & $55(55)$ & 1.67 & Disagree \\
\hline $\begin{array}{l}\text { Selection of contractors should not only be based on } \\
\text { lowest bid, but also on experience, financial capability } \\
\text { and expertise }\end{array}$ & $54(162)$ & $25(50)$ & $21(21)$ & 2.33 & Agree \\
\hline $\begin{array}{l}\text { Ensuring that there is no communication gap between } \\
\text { the professionals, the contractors, the clients and the } \\
\text { technicians. }\end{array}$ & $45(135)$ & $35(70)$ & $30(30)$ & 2.35 & Agree \\
\hline
\end{tabular}

Source: Field Survey, 2017

\section{Conclusion And Recommendations}

The study examined the causes and effects of cost overruns in public building construction projects delivery in Imo State Nigeria, by building construction projects stakeholders that include professionals, the client, the contractor, the technicians and the maternal suppliers from randomly selected Local Government Areas in Owerri Zone of Imo State. The result of the study indicated that $80 \%$ of the respondents were male and $80 \%$ of them also were married. A greater percentage of the respondents (54\%) are within the age bracket of 26 - 35 years. About $85 \%$ of the respondents are educated; this shows that the respondents were knowledgeable and therefore would not have problem with understanding and interpreting research questions. The respondents agreed that cost overruns occur when there is an underestimation of actual cost during the budgeting of the building construction project. They also agreed that cost overruns occurs when cost escalation occurs due to factors such as inflation, and when construction projects are not completed on time, within budget and with the appropriate technical or quality performance. The causes of cost overruns as agreed by the respondents are difficult in obtaining construction materials, deficiency in prepared cost estimates, unexpected subsoil conditions, problems in finance and payment arrangements, among others. The effects of cost overruns on the building construction industry and on the Nigerian economy in general agreed by the respondents include added cost over and above those initially agreed upon by the client, less return on investment on the part of the contractor, and higher prices or rent to the end user, tarnishing of the reputation of the professionals and loss of profits for the contractor. For the construction industry, the respondents said project abandonment and drop in building activities are the effect due to cost overruns. For the nations, the respondents said that decrease in property/service production and also decrease in rate of national growth are the effects due to cost avenues.

To help reduce or prevent cost overruns from occurring in building construction project delivery, the respondents agreed as follows:

(a) The professionals should apply project management tools in their project delivery;

(b) Both the client, the contractor and the professionals should strictly work within the scope originally planned for a project;

(c) Project should be planned properly before the commencement of project execution;

(d) Only contractors with adequate experience and the financial ability to handle building construction projects can be awarded contracts.

(e) Communication gaps should not exist between the stakeholders of the building construction projects. 
Finally, the respondents are of the opinion that, even though money is very essential in project delivery, adequate money does not have to be available before project implementation is commenced. If all these remedial measure are taken into consideration by those involved in building construction project delivery, it will go a long way in contributing to the solution for the problem of project cost overruns in Nigeria.

\section{References}

[1] Ahuja, FL, Dozzi, S. \& AbouRizk, S. (2009): Project Management Techniques in Planning and Controlling Construction Projects. 2nd ed., John Wiley \& Sons Inc., New York.

[2] Ameh, O.J., A.D. Soyingbe and K.T. Odusami,(2010): "Significant Factors Causing Cost Overruns in Telecommunication Projects in Nigeria". J. Constr. Develop. Count. 15(2): 49-67.

[3] Angelo, W.J. and P. Reina, (2002): Megaprojects Need More Study Up Front to Avoid Cost Overruns. McGraw-HilL New York.

[4] Arditi, D., Akan, G.T., Gurdamar, S., (2011): Reasons for delays in public projects in Turkey. Construction Management. Econ. 3, $171-181$.

[5] Avots, I. (1983): "Cost-Relevance Analysis for Overrun Control" International Journal of Project Management, Vol.1 No.3, 142-148.

[6] Azhar, N., R.U. Farooqui and S.M. Ahmed, (2010); "Cost Overrun Factors in Construction Industry in Pakistan". Proceeding of First International Conference on Construction in Developing Countries (ICCIDE-1), Karachi, Pakistan, 4-5 August, pp: 499-508

[7] Cantarelli, C.C., B. Flyvbjerg, B. Wee van, and E.J.E. Molin (2007): "Lock-In and Its Influence on the Project Performance of Large-Scale Transportation Infrastructure Projects". Investigating the Way in which Lock-In can Emerge and Affect Cost Overruns. Paper presented at the 88th annual meeting of the Transportation Research Board Washington, D.C.

[8] Cha and Shin, Compressing Construction Duration (2011): "Lesson Learned for Hong Kong Building Projects" pp. 20-,23-25.

[9] Doloi, A. (2011): “The rising cost of building construction". Shelter for Nigerians, NIA Publication, May Edition, pp. 18 - 19.

[10] Flyvbjerg, B., M. Holm and S. Buhl, (2003): "How Common and How Large are Cost Overruns in Transport Infrastructure Projects" Transportation Review, 23(1): 71-88.

[11] Frimpong, Y., J. Oluwoye and L. Crawford, (2003): "Causes of Delays and Cost Overruns in Construction of Groundwater Projects in Developing Countries"; Ghana as a case study. Int. J. Project Management, 21: 321-326.

[12] Greedy Garry, (2005): "Risk Factors Leading to Cost Overrun in Highway Projects", Queensland University of Technology, Australia.

[13] 1bbs, C. W., Wong, C. K. and Kwak, Y. H. (2001): "Project Change Management System D", Journal of Management in Engineering, vol. 17, no. 3 , pp. 159-165.

[14] Ibrahim, A.R., Roy, M.H., Ahmed, Z., Imtiaz, G., (2010). An Investigation of the Malaysian Construction Industries. Benchmarking 17 (2) 294-308.

[15] Kaming, I.S, et al, (1997): "Factors Influencing Construction Time and Cost Overrun on High-Rise Project in Indonesia" Constr. Manag. Econ. 15 (1), 83-94.

[16] Koushki, P.A., K. Al-Rashid and N. Kartam, (2005): "Delays and Cost Increases in the Construction of Private Residential Projects in Kuwait". Constr. Manag. Eco., 23(3): 285-294.

[17] Le-Hoai, L., Y.D. Lee and J.Y. Lee, (2008). "Delay and Cost Overruns in Vietnam Large Construction Projects": A comparison with other selected countries. KSCE J. Civ. Eng., 12(6): 367-377.

[18] Ugwu, Mansfield and Doran, (1994): "Causes of Delay and Cost Overrun in Nigeria Construction Industry", 12 (4), $245-260$.

[19] Mbachu J.I.C. and R.N. Nkado. (2004) "Reducing Building Construction Costs the Views of Consultants and Contractors". COBRA

[20] Memon, A.H., I. Abdul Rahman, M.R. Abdullah and A.A. Abdu Azis, (2010): "Factors Affecting Construction Cost in Mara Large Construction Project". Perspective of Project Management Consultant. Int. J. Sustain. Constr. Eng. Techno!., 1(2)

[21] Olawale, Y. A., \& Sun, M. (2010): "Cost and time control of construction projects: inhibiting factors and mitigating measures in practice. Construction Management and Economics, 28(5), 509-526.

[22] Omoregie, A. and D. Radford, 2006. "Infrastructure Delays and Cost Escalation: causes and effects in Nigeria". Proceeding of Sixth International Postgraduate Research Conference, Delft University of Technology and TNO, the Netherlands. 3-7 April.

[23] Robert F. Cox, (2007), "Key Elements to Successful International Collaboration in Construction Project Delivery", The proceedings of The International Conference of Construction and Real Estate Management, Beijing, China, ISBN 978-7-89475-107-2, pg 14201425 . 